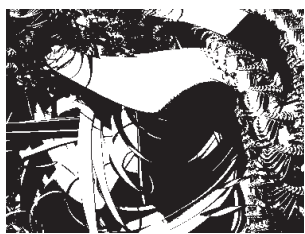

\title{
O KONCEPTU PODUZETNIČKOGA SVEUČILIŠTA: IMA LI ALTERNATIVE?
}

Marina DABIĆ

Ekonomski fakultet, Zagreb

Jadranka ŠVARC

Institut društvenih znanosti Ivo Pilar, Zagreb

UDK: 65.012.4:378.3

Pregledni rad

Primljeno: 7. 3. 2011.

Kriza sveučilišta iz 1970-ih godina, potaknuta smanjenjem proračunskih sredstava, doživljava danas u sklopu globalne financijske krize svoju reprizu. lako se doprinos sveučilišta gospodarskom razvoju preko standardnih funkcija znanstvenih istraživanja i obrazovanja smatra neupitnim, upitno je jesu li ove funkcije, u uvjetima ekonomija znanja, dostatne sveučilištu kako bi zadržalo do sada vodeći položai proizvođača znanja i intelektualnoga kapitala. To otvara vrata novim modelima sveučilišta, među kojima dominira poduzetničko sveučilište i njegova recentna inačica - treća generacija sveučilišta. Oba modela naglašavaju važnost doprinosa sveučilišła gospodarskom razvoju i izloženost sveučilišta globalnoj kompeticiij. U tom kontekstu, rad analizira koncept poduzetničkoga sveučilišta, povijesni kontekst nastanka te teorijsko-analitičke okvire koji su doveli do promjene u paradigmi sveučilišnih istraživanja i transformacije iz tradicionalnoga sveučilišta u poduzetničko. Rad također objašnjava djelatnosti poduzetničkoga sveučilišta te daje i osvrt na položaj poduzetničkoga sveučilišta u Hrvatskoj. Zaključuje da su sva sveučilišta, pa i ona u inovacijski manje razvijenim zemljama kao što je Hrvatska, izložena globalizaciji i internacionalizaciii, što ih neminovno sili na promiene. Stoga je malo vjerojatno da će sadašnii način funkcioniranja sveučilišta pod okriljem države, a bez suradnje s gospodarstvom, biti održiv na dulii rok.

Ključne riječi: poduzetničko sveučilište, treća generacija sveučilišta, povijesni razvoi, promiena paradigme, teorijski okviri, Hrvatska 
Moderno sveučilište suočava se, od samih svojih početaka koje konvencionalno označuje osnutak tzv. Humboldtova sveučilišta u Berlinu 1809. godine, s dvostrukim, za mnoge oprečnim, ciljevima istraživanja: potrage za fundamentalno novim znanjima koja teže pridonijeti kvaliteti teorijske nastave kao suštinske djelatnosti sveučilišta i potrage za primijenjenim znanjima koja pridonose praktičnoj nastavi i imaju neposrednu tehnološku primjenljivost i komercijalnu iskoristivost.

Dok je u Europi ova oprečnost istraživačkih ciljeva, ali i ukupne znanstveno-obrazovne usmjerenosti sveučilišta i dalje vrlo aktualna te se odražava na suprotstavljanje koncepta istraživačkoga i poduzetničkoga sveučilišta, američka su sveučilišta oduvijek bila okrenuta prema praktičnoj nastavi i primjeni. Američka je vlada još 1862. godine Morrillovim zakonom dodijelila fakultetima zemlju kao oblik financijske potpore (tzv. "land-grant" sveučilišta) za njihov rad, čime je uspostavljena ravnoteža "praktične i liberalne nastave," tj. poticanje poljoprivrednih i inženjerskih umijeća te znanstvenih i klasičnih studija. Tradicija poduzetništva znatno jača u 1980-im i 1990-im godinama ulogom rizičnoga kapitala, znanstvenim parkovima, tehnološkim transferom i spin-off poduzećima, praksama koje u Europi još nisu potpuno zaživjele.

Za razliku od toga, u Europi se osjeća institucionalna inercija sveučilišta u odnosu na potrebu prilagodbe zahtjevima ekonomiji znanja, u kojoj stvaranje, ali i iskorištavanje, znanja u svrhu gospodarske konkurentnosti i razvoja čini osnovu njezina funkcioniranja. Realizacija mnogih strateških dokumenata Europske komisije o modernizaciji sveučilišta (npr. COM, 2006.), koja podrazumijeva provedbu Bolonjskoga procesa, ali i sve veću orijentaciju prema tržištu, spora je i sporadična.

U sklopu tranzicije znanstveno-istraživačkoga sustava (Cozzens i sur., 1989.; Gibbons, i sur., 2006.) i nacionalnih inovacijskih sustava (Nelson, 1993.) institucije sudjeluju u stvaranju, difuziji i upotrebi znanja, a sveučilišta tek su jedan, iako važan, segment $u$ procesu proizvodnje i kapitalizacije znanja. Znanstvena istraživanja više nisu povlastica sveučilišta, pa se ono našlo u kompeticiji s ostalim kreatorima znanja. Isto tako, globalizacija i mobilnost studenata sili današnja sveučilišta na kompeticiju s mnogim sveučilištima diljem svijeta, uključujući sveučilišta s Dalekog istoka, koja ozbiljno prijete primatu ne samo europskih nego i američkih sveučilišta. Radikalna stanovišta drže da je tradicionalno sveučilište Humboldtova tipa danas pred slomom i da više ne funkcionira (Wissema, 2009.). Preraslo je u suvišne kompleksne institucije (pre)opterećene raznim funkcijama, kao što su predavanja, istraživanja i publikacije, pružanje usluga društvu, suradnja s gospodarstvom, 
DRUŠ. ISTRAŽ. ZAGREB GOD. 20 (2011), BR. $4(114)$

STR. 991-1013

DABIĆ, M., ŠVARC, J.: O KONCEPTU.. patentiranje i transfer tehnologije, a podložne su i administrativno-birokratskim intervencijama javne uprave (Decter i sur., 2007.). Stoga je sve aktualnija koncepcija tzv. treće generacije sveučilišta (Wissema, 2009.), koja nastoji pomiriti konflikte na sadašnjim sveučilištima i koja će se u bespoštednoj globalnoj utrci za najbolje studente, profesore i ugovore $s$ industrijom etablirati kao središta elitnog obrazovanja i komercijalizacije istraživanja na globalnoj razini.

Važno je istaknuti kako je neupitan doprinos sveučilišta tehnološkom razvoju preko standardnih funkcija znanstvenih istraživanja i obrazovanja. Upitno je jesu li ove funkcije, u uvjetima ekonomija znanja, dostatne sveučilištu kako bi zadržalo do sada vodeći položaj proizvođača znanja i intelektualnoga kapitala.

\section{TERMINOLOŠKO RAZGRANIČENJE KONCEPTA PODUZETNIČKOGA SVEUČILIŠTA}

U kontekstu poduzetništva na sveučilištu susreću se razni termini koji nastoje objasniti "tržišno ponašanje" sveučilišta, njegovu "komercijalnu usmjerenost" radi "osiguranja vanjskih sredstava" kao što je "poduzetničko sveučilište", "akademski kapitalizam", "korporativno sveučilište" i sl. Iako se ovi termini u velikom broju slučaja rabe za opis istih djelatnosti, među njima postoje i razlike koje se nastoje preciznije definirati.

Akademski kapitalizam definiran je kao institucionalna i profesionalna tržišna usmjerenost sveučilišta ili tržišni napori za osiguranje eksternih prihoda na sveučilištu (Slaughter i Leslie, 1997., 8), dok se pod komercijalizacijom visokog obrazovanja razumijevaju uglavnom napori unutar sveučilišta usmjereni prema stvaranju zarade iz nastave, istraživanjima i drugim sveučilišnim aktivnostima (Bok, 2003., 3).

$\mathrm{U}$ radu o vezama industrije i sveučilišta, $u$ istraživanju provedenom u prirodnim znanostima, Etzkowitz i sur. (2000.b) rabe riječ "komercijalizacija", pri tome opisujući procese kapitalizacije znanja preklapanjem akademskoga svijeta, industrije i javne uprave. Clark (1998.) u svojem radu o transformaciji pet europskih sveučilišta uključenih u tranziciju sveučilišta prema poduzetničkom sveučilištu također rabi pojam "entrepreneurial" (poduzetničko). Vogel (2004.) govori o "komercijalnim praksama u visokom obrazovanju". Riječ "entrepreneurialism" rabi se i kada je riječ o nastojanju sveučilišta glede zadovoljenja komercijalnih kriterija i ostvarenja dobiti. Brint (2000.) govori o "entrepreneurialismu" u visokom obrazovanju i definira ga kao "napor sveučilišta i djelatnika u kapitaliziranju istraživačkih otkrića" (str. 246). Pojam entrepreneurialism rabe u svojem radu i neki domaći autori, kao Vizek Vidović i Bjeliš (2006.). Marginson i Considine (2000.) pišu o "sveuči- 
DRUŠ. ISTRAŽ. ZAGREB GOD. 20 (2011)

BR. 4 (114),

STR. 991-1013

DABIĆ, M., ŠVARC, J.: O KONCEPTU... lištu kao poduzeću", ustrojenom u skladu s načelima korporativnog upravljanja na primjeru Australije, gdje je javna uprava drastično pojačala menadžerski pristup na sveučilištima. Spomenuti autori preferiraju "sveučilište kao poduzeće" jer "obuhvaća i ekonomsku i akademsku dimenziju" i ono podjednako ostvaruje institucionalnu reputaciju kao i generiranje prihoda. Sličan je i koncept korporativnoga sveučilišta, koji ostvaruje obrazovne ciljeve neke institucije, obično korporacije, kao što je Motorola ili Toyota (Allen, 2002.).

U ovom se radu pod pojmom poduzetničkoga sveučilišta razumijeva sveučilište koje rabi razne mehanizme za izravno uključenje $u$ iskorištavanje istraživačkih rezultata za dobrobit društvene zajednice na lokalnoj i nacionalnoj razini. Naglasak je na intenzivnoj suradnji s poslovnim sektorom i eksploataciji rezultata istraživanja uz uključivanje u regionalni razvoj. Pritom se tradicionalna (obrazovna i znanstvena) uloga sveučilišta smatra conditio sine qua non sveučilišne misije. Ona uključuje traganje za novim spoznajama, stalno propitkivanje i poticanje znatiželje te zastupanje etičkih i znanstvenih vrijednosti i normi. Poduzetničke funkcije dograđuju ove bitne djelatnosti i podrazumijevaju nov način upravljanja sveučilištem, koje se temelji na: 1. akademskoj upravi koja može formulirati stratešku misiju, ciljeve i viziju te ih primijeniti; 2. kontroli svih izvora (zemljište, zgrade, intelektualno vlasništvo i financijski prihodi dobiveni na temelju istraživanja); 3. organizacijskim kapacitetima koji mogu transferirati tehnologiju kroz inkubaciju poduzeća, patente i licence, 4 . poticanju i razvoju poduzetničkoga duha među studentima, profesorima i administrativnim osobljem, 5. mogućnosti stvaranja mreža i suradnje s drugim sveučilištima i institucijama na individualnom, istraživačkom i institucionalnom nivou, 6. mogućnosti uspostavljanja dijaloga i razumijevanja s gospodarstvom.

\section{PROMJENA SVEUČILIŠNE PARADIGME ILI TRANSFORMACIJA ULOGE SVEUČILIŠTA}

Među teorijama o promjeni znanstvenih i sveučilišnih sustava ističu se tri:

1. Novi model proizvodnje znanja (Gibbons i sur., 2006.), koji podrazumijeva heterogenost, interdisciplinarnost i umrežavanje s naglaskom na kooperativnim istraživanjima i suradnji znanosti i industrije

2. Teza o drugoj sveučilišnoj revoluciji (Etzkowitz, 1998.) koja dovodi do poduzetničkoga sveučilišta

3. Model "trostruke uzvojnice" (Leydesdorff i Etzkowitz, 1998.), koji zastupa tezu o preklapanju aktivnosti sveučilišta, javne uprave i industrije te potrebu njihove međusobne kooperacije. 
DRUŠ. ISTRAŽ. ZAGREB GOD. 20 (2011), BR. 4 (114)

STR. 991-1013

DABIĆ, M., ŠVARC, J.: O KONCEPTU..
Iako su sve tri teorije izvrgnute oštroj kritici svojih oponenata, nesumnjivo je da su dale pečat razvoju sustava znanosti i znanstvene politike, vidljive i danas. Zajedničko im je to što rade odmak od standardne uloge sveučilišta u kojoj je sveučilište neupitan "prvi pokretač" inovacije i gospodarskoga rasta jer stvara temeljna znanja, prema novoj ulozi sveučilišta kao jednog od mnogobrojnih subjekata koji pridonose tehnološkoj promjeni s naglaskom na primjeni, a ne samo kreaciji znanja.

U tom su kontekstu teorija o sustavu inovacija (Mytelka i Smith, 2002.) i koncept nacionalnoga inovacijskog sustava (Freeman, 1988.; Nelson, 1993.) znatno pridonijeli promjeni sveučilišne paradigme od tradicionalnoga prema poduzetničkom sveučilištu. Naime, bit je inovacijskih sustava u međudjelovanja znanosti i gospodarstva (Rosenberg, 1985.; Rosenberg i Nelson, 1994.) te protoku znanja i međusobnom učenju ovih sektora (Lundvall, 1992.) radi stvaranja inovacija. To je ujedno i glavni mehanizam uključivanja sveučilišta u gospodarski razvoj, koji će rezultirati raznovrsnim djelatnostima sveučilišta koje se danas svrstavaju u poduzetničke.

Povijesno gledajući, promjena paradigme ili transformacija uloge sveučilišta počinje u vrijeme krize 1970-ih godina, kada na političku scenu stupa fenomen "nacionalne gospodarske konkurentnosti" i izgradnje nacionalnih inovacijskih sustava (NIS) radi prevladavanja tehnološkoga zaostajanja, i to prije svega Amerike u odnosu na Japan (Freeman, 1988.). Revitaliziraju se pitanja oko izvora gospodarskoga rasta, te jačaju uvjerenja kako znanstvene spoznaje neće same po sebi dovesti do tehnološkog napretka, nego je potrebna njihova pretvorba $u$ inovacije koje znanstvena znanja kapitaliziraju, odnosno pretvaraju u novu tržišnu vrijednost. U idućim desetljećima trend razvoja NIS-a širi se svijetom, pa i na tranzicijske zemlje, te jača spoznaja da je razvoj domaćih znanstveno-istraživačkih potencijala, uključujući sveučilišnu znanost, nužan, ali ne i dovoljan, uvjet nastanka tehnološke inovacije koja stvara nacionalnu konkurentnost. Gospodarska kriza dovodi do smanjenja budžeta za znanost i označuje početak, prema De Solla Price, "stagnirajućeg" statusa znanosti (Cozzens i sur., 1989.), što rezultira preispitivanjem uloge znanosti uopće, pa i sveučilišnih istraživanja u gospodarskom razvoju. Javljaju se modeli "nove proizvodnje znanja" (Gibbons i sur., 2006.), koji u biti označavaju takav način istraživanja koji je bliži industrijskom, a ne akademskom idealu istraživanja i zapravo opisuje istraživanja koja se odvijaju u suradnji znanosti i industrije. Isto tako s rastućim prepletanjem znanosti i tehnologije, "scijentizacijom" industrije i sve većom ovisnošću tehnologije o istraživanjima i obrnuto, sveučilište doživljava svoju 1. revo- 
DRUŠ. ISTRAŽ. ZAGREB GOD. 20 (2011)

BR. 4 (114),

STR. 991-1013

DABIĆ, M., ŠVARC, J.: O KONCEPTU... luciju, koja označuje nastanak tzv. istraživačkoga sveučilišta koje obrazovnoj funkciji, kao do sada isključivoj djelatnosti, pridodaje i funkciju istraživanja, smatrajući je nužnom za kvalitetno obrazovanje sveučilišnih stručnjaka.

Transformaciju sveučilišta, odnosno promjenu paradigme sveučilišta kroz dvije sveučilišne revolucije najbolje je opisao Etzkowitz (2008.). On je učio da se europska sveučilišta drugačije razvijaju nego američka te da je prva sveučilišna revolucije karakteristična uglavnom za europska sveučilišta. Europska sveučilišta tek su nakon prve sveučilišne revolucije, koja se veže uz osnutak Humboldtova sveučilišta, prerasla u istraživačka sveučilišta, i to prije svega temeljnih znanosti, a američka su sveučilišta istraživačka od samoga početka, i to najčešće u primijenjenim znanostima. Prva sveučilišna revolucija dogodila se u Njemačkoj sredinom 19. st., kada se sveučilište otkinulo od svojega srednjovjekovnog podrijetla (očuvanje i prijenos postojećega znanja) i transformiralo u instituciju koja proizvodi novo znanje, u tzv. istraživačko sveučilište.

Temelji druge sveučilišne revolucije nedvojbeno su postavljeni u Americi, a proizlaze iz tradicionalne ukorijenjenosti američkih sveučilišta u regionalni gospodarski razvoj (Etzkowitz, 1998.). Druga sveučilišna revolucija veže se uz pojavu poduzetničkoga sveučilišta, koje izrasta iz potrebe da sveučilišta budu odgovornija prema proračunskim sredstvima, da u većoj mjeri nabave sredstva za svoja istraživanja na tržištu te da se uključe u ekonomski razvoj (Etzkowitz, 2008., 30). Korijeni ove revolucije položeni su još nakon Drugoga svjetskog rata, kada se državna sredstva za sveučilišta smanjuju, a izdvajanja gospodarstva te pojava privatnih fondova povećavaju (Bouroche, 2001.) u odnosu na eksponencijalni rast s početka šezdesetih godina prošloga stoljeća. Tada je znanost bila, sama po sebi, jamstvo i neupitan izvor općega blagostanja.

Jedan od najpopularnijih modela kojim se objašnjava pojava i funkcioniranje poduzetničkoga sveučilišta jest model trostruke uzvojnice, koji produkciju znanja i inovacija u uvjetima gospodarstva znanja vidi kao interakciju triju ključnih sudionika: sveučilišta, vlade i države (Leydesdorff i Etzkowitz, 1998.; Etzkowitz, 2008.). Iako od samoga početka on izaziva čitav niz kontroverzi, model trostruke uzvojnice analitički je okvir i korisna teorijska platforma koja normativnim pristupom u društvenim istraživanjima nastoji objasniti ulogu znanja i društvenih struktura u gospodarskom razvoju. Za razliku od inovacijskoga sustava, u središtu kojega je inovativno poduzeće, $\mathrm{u}$ središtu modela trostruke uzvojnice jest sveučilište koje stvara znanje. Međutim, to se znanje stvara na nov način, ne samo u okrilju sveučilišta nego i u međudjelovanju sveučilišta, vlade i gospodarstva, odnosno njihovoj konvergenciji kroz proces koevolucije, stalne interakcije i prilagodbe. U zreloj fazi jedna uzvojnica ili sustav može poprimiti ka- 
DRUŠ. ISTRAŽ. ZAGREB GOD. 20 (2011), BR. 4 (114)

STR. 991-1013

DABIĆ, M., ŠVARC, J.: O KONCEPTU.. rakteristike one druge, pa tako sveučilište ili istraživačka grupa može imati karakteristike poduzeća, a poduzeće zadobiti obrazovnu ili istraživačku funkciju u sklopu razvojnih konzorcija ili mreža znanja.

Koncepcija poduzetništava $u$ visokom obrazovanju ima sve više sljedbenika, jer povećava odgovornost i odjeljuje financije uz reguliranje učinkovitosti troškova. Zagovornici poslovnoga modela visokog obrazovanja tvrde kako moderne teorije menadžmenta (od kojih se mnoge usredotočuju na rezultate više nego na mikromenadžment ulaznih resursa) mogu pomoći u svladavanju birokratske inercije, koja je često zapreka intelektualnoj, upravljačkoj i pedagoškoj inovaciji na sveučilištima. Brint (2000.) misli kako novo sveučilište nije samo poduzetnije od staroga, nego je fleksibilnije i jače kao posljedica poduzetničkih aktivnosti. Clark (1998.) ističe kako učinkovito kolektivno poduzetništvo ne vodi sveučilište izvan granica akademske legitimnosti srozavajući njegov ugled, resurse i razvoj. Naprotiv, ono, po njemu, stvara resurse i infrastrukturu koja otvara mogućnosti izvan očekivanih i omogućuje mu uzlazne trendove u kvaliteti i reputaciji. Pri tome razlikuje pet načina organizacijske transformacije koji vode prema jačanju poduzetničkoga sveučilišta: ojačana upravljačka jezgra, proširena razvojna periferija, diverzificirana financijska baza, stimulirano akademsko središte i integrirana poduzetnička kultura (str. 5).

Današnja uloga sveučilišta teži daljnjoj transformaciji, koja se može opisati kao pomak od sveučilišta kao tvornice znanja prema sveučilištu kao koncentratoru znanja, s nakanom unapređenja tehnološke inovacije i ekonomskoga razvoja u zemlji. Umreženo s ostalim akterima razvoja, ono bi trebalo poticati razvoj u regiji (Goldstein i Renault, 2004.).

Prema modelu Youtie i Shapira (2008.), sveučilišta postaju još dublje uvučena u sustav inovacija, tražeći aktivno poticanje interakcije, prelijevanja i povezivanja istraživanja s aplikacijom i komercijalizacijom. Slaughter i Rhoades (2004.) zalažu se za "tvrđu" varijantu u akademskom kapitalizmu, tj. drže da se sveučilišta trebaju izboriti za svoje mjesto u novoj ekonomiji borbom za najbolje studente i agresivnom komercijalizacijom intelektualnih prava na svoja istraživanja. Ovo je mišljenje na tragu koncepta treće generacije sveučilišta, koja se etabliraju u kompeticiji s ostalim sveučilištima na globalnoj razini (Wissema, 2009.).

\section{O KONCEPTU PODUZETNIČKOGA SVEUČILIŠTA}

Sveučilišta, tradicionalno, imaju dvojaku misiju: istraživanje i poučavanje. Danas, s pojavom nove sveučilišne paradigme, sveučilišta imaju i treću ulogu, a to je njihov doprinos gospodarskom razvoju na lokalnoj i regionalnoj razini (Readings, 
DRUŠ. ISTRAŽ. ZAGREB GOD. 20 (2011)

BR. 4 (114),

STR. 991-1013

DABIĆ, M., ŠVARC, J.: O KONCEPTU... se kao važan faktor gospodarskoga rasta i tehnološkoga razvoja (Tornatzky i sur., 2002.). Danas se od sveučilišta očekuje razvoj triju vrsta aktivnosti: prva vrsta aktivnosti odnosi se na shvaćanje individualnih akademskih aktivnosti kao poduzetničkih (npr. profesori se sami brinu o sredstvima za istraživačke projekte, znanstvena putovanja i sl.), akademsko objavljivanje radova, stipendije i ugovorna istraživanja; druga skupina aktivnosti odnosi se na patentiranje, licenciranje i stvaranje spin-off poduzeća; treća skupina aktivnosti odnosi se na konzultantske usluge i doprinos regionalnom razvoju. Prva skupina smatra se tradicionalnim aktivnostima za većinu sveučilišta te ne izaziva previše prijepora. Slično je i s trećom skupinom aktivnosti, jer su konzultacije također standardna aktivnost sveučilišta koju danas dopunjuje uključivanje sveučilišta u regionalni razvoj. Druga skupina aktivnosti izaziva ponajviše prijepora, etičkih dilema i diskusija o njihovoj korisnosti, odnosno štetnosti, za sveučilište. Od 1980-ih nekoliko je čimbenika značajno utjecalo na povećanje sveučilišnih spin-off poduzeća, a među najzapaženijim čimbenicima jesu: razvoj biomedicinske tehnologije, promjene u patentnim zakonima, porast iskorištenja kapitala od sveučilišta, promjene u procesu financiranja (Shane, 2004.). U Americi posebno valja istaknuti ulogu Bayh-Doleova zakona iz 1980. godine (Mowery i sur., 2001.), koji je omogućio sveučilištima nesmetano raspolaganje rezultatima istraživanja, $\mathrm{i}$ to upravljanjem pravima intelektualnoga vlasništva. Bayh-Doleov zakon rezultirao je pojednostavnjenjem procedure koja prati licenciranje i komercijalizaciju izuma financiranih državnim novcem. Prema Shane (2004.), ovo pojednostavnjenje otvorilo je značajan prostor sveučilištima za patentiranje, što je rezultiralo porastom broja patenata, licenci i tantijema. Te aktivnosti mogu imati neprocjenjivu ekonomsku vrijednost. Procjenjuje se kako se 33 milijarde dolara gospodarske aktivnosti SAD-a i 280000 radnih mjesta može pripisati akademskom licenciranju tehnologije (Shane, 2004.). Istodobno, samo u 2006. godini u SAD-u su država i poduzeća investirala više od 45 milijardi američkih dolara kao podršku istraživanjima na sveučilištima. Kao rezultat navedenoga, razvijeno je više od 700 novih proizvoda, koji su, kroz transfer tehnologije sa sveučilišta, našle svoju primjenu (Nelson, 2001.). Neka od njih jesu: CAD-programiranje pomoću računala, lijek za karcinom taxol, PSA test za karcinom prostate, testovi za otkrivanje osteoporoze i karcinoma dojke, sintesajzer, radarsko praćenje oluja itd. Samo na sveučilištu Yale broj patenata enormno je porastao. Dok 1981. godine nije odobren ni jedan patent, 1990. godine odobreno ih je 15, a 2009. 155. U razdoblju od 1981. do 2009. odobreno je ukupno 970 patenata (Yale, 2009.).

Clark (1998., 2001.), dajući teorijske temelje za sveučilišna istraživanja, tvrdi kako je prvo obilježje inovativnosti sposob- 
DRUŠ. ISTRAŽ. ZAGREB GOD. 20 (2011), BR. 4 (114)

STR. 991-1013

DABIĆ, M., ŠVARC, J.: O KONCEPTU.. nost samopromjene. Ono otvara prostor za kontekstualnu usmjerenost sveučilišta prema tzv. integriranoj administrativnoj jezgri i diskrecijskoj osnovi za financiranje inovacija. Integrirana administrativna jezgra spoj je menadžerske i sveučilišne vlasti, a diskrecijska osnova pretpostavlja uvođenje novih i netradicionalnih izvora financiranja inovacija. Kennedy (1997.) ističe kako bi javna sveučilišta bolje djelovala na tržišnim principima. Drugim riječima, poduzetnički odgovor na sve veću neravnotežu između okruženja i sveučilišta daje sveučilištu bolju priliku da kontrolira vlastitu sudbinu.

Smatra se kako će određene aktivnosti, koje podupiru razvoj gospodarstva, omogućiti financijsko napredovanje i samoga sveučilišta. Neka od sveučilišta, kao: Stanford, MIT, University of California, Columbia, Cambridge, University of Waterloo, Kanada; Chalmers University of Technology, Śvedska, Leuven iz Belgije itd. već duže imaju naglasak upravo na spomenutim poduzetničkim aktivnostima (Clark, 1998.; Etzkowitz i sur., 2000.a; Mowery i sur., 2001.). Ipak, poduzetništvo još nije karakteristika većine sveučilišta. Suprotan je primjer Sveučilište Hopkins, koje je unatoč uspjehu i konceptu poduzetničkoga sveučilišta slabo utjecalo na regionalni razvoj u smislu stvorenih spin-off poduzeća i suradnje s gospodarstvom (Feldman, 1994.; Feldman i Desrochers, 2003.). Nažalost, ono nije slijedilo uspjeh dobro poznatih Stanforda i MIT-a. Prijenos tehnologije bolje funkcionira na onim sveučilištima koja shvaćaju kako komercijalizacija izuma kroz licence s nacionalnim kompanijama ili kroz lokalne start-up kompanije pomaže regionalnom gospodarskom razvoju.

Međutim, koncept poduzetničkoga sveučilišta često se netočno izjednačava samo s komercijalizacijom istraživanja, brojem patenata, licenci, ugovornih istraživačkih projekata i spin-off poduzeća (Lockett i sur., 2005.). Stoga su i evaluacije uspješnosti sveučilišta često danas vrlo usko koncipirane i usmjerene prije svega na ispitivanje kapaciteta sveučilišta potrebnih za proizvodnju "čvrstog" rezultata, kao što je patentiranje i osnivanje "start up" poduzeća, (Ratinho i Henriques, 2010.; Baldini, 2010.; Hoye i Pries, 2009.), a manje na aktivnosti koje se smatraju klasičnim za djelatnosti institucija visokog obrazovanja.

Prema opširnom istraživanju Lumpkina i Dessa (1996.), poduzetništvo na sveučilištu ima pet dimenzija: autonomiju, inovativnost, poduzimanje rizika, proaktivnost i kompetitivnu agresivnost. Uz navedene dimenzije, jedno od najvažnijih obilježja poduzetništva na sveučilištima jest samoobnova (Bolton i Thompson, 2004.). Prema Gibb i sur. (2009.), obnova se odnosi na promjene i poboljšanje veza s vanjskom okolinom, a akademsko osoblje, koje je blisko povezano sa svijetom izvan sveučilišta i koje unapređuje njihovu vezu s ciljanom industrijom, pokazuje poduzetničke aktivnosti. 
DRUŠ. ISTRAŽ. ZAGREB GOD. 20 (2011)

BR. 4 (114),

STR. 991-1013

DABIĆ, M., ŠVARC, J.: O KONCEPTU...
Koncept poduzetničkoga sveučilišta danas se sve više zamjenjuje novom varijantom, a to je treća generacija sveučilišta (3GS) (Wissema, 2009.), koja nastoji razriješiti niz konflikata s kojima se suočava moderno sveučilište, kao npr. konflikt znanstvenih istraživanja i poduzetničke orijentacije, masovnog i elitnog obrazovanja, lokalnoga djelovanja i globalne kompeticije. Wissema (2009.) navodi 8 glavnih karakteristika 3GS, koje se mogu sažeti ovako:

- $\quad$ središnja aktivnost 3GS jesu i nadalje fundamentalna istraživanja, a kreativnost i znanstvene metode ostaju njihovi pokretači; iskorištavanje znanja i vještina postaje treći sveučilišni cilj, s obzirom na to da se sveučilišta vidi kao kolijevka novih poduzetničkih aktivnosti

- 3GS umrežena su sveučilišta koja surađuju s industrijom, privatnim i javnim istraživačkim institucijama, financijerima te ostalim sveučilištima na stvaranju znanja i vještina

- 3GS su kozmopolitska, jer njihovo osoblje i studenti dolaze iz međunarodnog okruženja, a radni jezik postaje engleski

- 3GS kombiniraju masovno obrazovanje s posebnim programima za najbolje studente

- $\quad$ GGS će postati manje ovisni o državnim propisima, a proračunska sredstva više se neće dodjeljivati izravno, nego preko nezavisnih financijskih institucija.

\section{PROTIVNICI KONCEPTA PODUZETNIČKOGA SVEUČILIŠTA}

Komercijalna komponenta u novoj proizvodnji znanja izazvala je reakcije u akademskoj zajednici s osnovnom porukom o njezinoj štetnosti za autonoman i slobodan razvoj znanosti. Postoji mnogo radova u kojima autori izražavaju zabrinutost zbog pojave akademskoga poduzetništva, odnosno akademskoga kapitalizma (Slaughter i Leslie, 2001.), a mnogi drže da je to dio većega kompleksa neoliberalne hegemonije (Carroll i Beaton, 2000.).

Keller (1983.) smatra da termin poduzetničko sveučilište obuhvaća "menadžersku revoluciju u akademiji", koja označuje jaču stratešku kontrolu razvoja fakulteta i sveučilišta, uključujući i menadžment sveučilišta. Jedna je takva promjena i ta da rektor ne mora biti iz akademskih krugova. To je česta praksa u SAD-u, a vrlo rijetka u Europi.

Kogan i Kogan (1983.) te Soley (2000.) ističu kako tržišno upravljano sveučilište prijeti proizvodnji znanja i time nije konzistentno s tradicijom visokog obrazovanja, pa iskazuju zabrinutost za budućnost sveučilišta. Slaughter i Leslie (2001.) tvrde kako akademski kapitalizam restrukturira visoko obrazovanje i uvodi osjetne organizacijske promjene, primjerice, $u$ unutarnjoj raspodjeli resursa, organizaciji odjela, rastu administracije i podjeli akademskoga rada na predavanje i istraživanje. Znanstvenici u tradicionalnim disciplinama uglavnom 
DRUŠ. ISTRAŽ. ZAGREB GOD. 20 (2011), BR. $4(114)$

STR. 991-1013

DABIĆ, M., ŠVARC, J.: O KONCEPTU.. radije odabiru akademski život nego tržišni, djelomice i zbog toga što traganje za istinom i znanjem smatraju vrednijim pozivom od potrage za materijalnim bogatstvom (Bok, 2003.). Ovi autori također tvrde da poduzetnička sveučilišta pogrešno postupaju jer izdaju tradicionalne akademske vrijednosti, oportunisti su u poučavanju i istraživanju, zanima ih samo zarada i zato poduzimaju sve vrste nepotrebnih aktivnosti, stranih sveučilišnoj praksi.

Iako nova poduzeća koja stvara sveučilište čak i za protivnike poduzetničkoga sveučilišta znače pozitivan utjecaj, oni ipak čvrsto vjeruju kako je obrazovanje radne snage mnogo važnija uloga sveučilišta. Obrazovanje je često, po njihovu mišljenju, zanemaren doprinos sveučilišta u podizanju intelektualnoga kapitala regije i država. Temeljna su istraživanja također vrlo važna za sveučilište (Salter i Martin, 2001.), jer ona mogu biti predmetom transfera tehnologije i mogu unaprijediti procese industrije kroz novi instrumentarij i metodologiju ili stvaranjem "neopipljivog" znanja, koje će rezultirati zapošljavanjem radne snage. Rang i sur. (2003.) smatraju da razvoj tradicionalnih aktivnosti može biti koristan za razvoj "čvrstih poduzetničkih rezultata". Iako je interakcija znanosti i industrije te integracija znanosti i tehnologije podvrgnuta sve većoj kritici, navedena interaktivnost duboko je ukorijenjena u prirodi i tijeku nastanka industrija znanja, koje su dovele do današnjega društva znanja. Unutar Hrvatske i u EU-u čak i među protivnicima koncepta poduzetničkoga sveučilišta postoji suglasnost oko postojanja značajne koristi od podupiranja sveučilišnih poduzetničkih aktivnosti, iako one ne bi smjele prevladati nad tradicionalnom ulogom sveučilišta.

\section{DJELATNOSTI PODUZETNIČKOGA SVEUČILIŠTA}

Literatura o ulozi i djelatnostima poduzetničkoga sveučilišta brojna je i fragmentirana da bi dala koherentnu i jednoznačnu teoriju poduzetničkih djelatnosti sveučilišta. Primjerice, analiza 173 članka o poduzetničkom sveučilištu (Rothaermel i sur., 2007.) grupirala je teme vezane uz poduzetništvo na sveučilištu u četiri glavna smjera: (i) poduzetničko istraživačko sveučilište, (ii) produktivnost ureda za transfer tehnologija, (iii) stvaranje novih poduzeća i (iv) poduzetnički kontekst, uključujući inovativne mreže. Stoga se djelatnosti poduzetničkoga sveučilišta mogu sistematizirati samo tentativno, primjerice:

1. Istraživačka i stručna suradnja s poduzećima

2. Komercijalizacija rezultata istraživanja zaštitom prava intelektualnoga vlasništva, tj. patentima i licencama

3. Osnivanje spin-off poduzeća ili akademsko poduzetništvo u užem smislu

4. Osnivanje inovacijske i tehnološke infrastrukture za suradnju znanosti i gospodarstva, kao što su: 
DRUŠ. ISTRAŽ. ZAGREB GOD. 20 (2011) BR. 4 (114),

STR. 991-1013

DABIĆ, M., ŠVARC, J.: O KONCEPTU... sveučilišni znanstveni i tehnološki parkovi sveučilišni uredi za transfer tehnologije

5. Primjena strateškoga partnerstva i rizičnoga kapitala u komercijalizaciji istraživanja i u osnivanju spin-off poduzeća

6. Međusektorska mobilnost kadrova i poticanje stručne nastave za potrebe gospodarstva

7. Uključivanje u projekte lokalnoga i regionalnoga razvoja, najčešće raznim modelima javno-privatnoga partnerstva.

Najčešći mehanizmi suradnje sveučilišta i gospodarstva jesu istraživački projekti koji mogu obuhvatiti nekoliko tipova projekata, među kojima su ugovorna istraživanja i pružanje rutinskih stručno-znanstvenih usluga (mjerenje, kontrola kvalitete i sl.) standardni oblici. Također, mnoga sveučilišta sudjeluju u zajedničkim istraživačkim projektima i konzorcijima s gospodarskim subjektima u kojima se naglašava partnerski odnos svih dionika.

Sljedeći mehanizam komercijalizacije istraživanja jest transfer intelektualnoga vlasništva sa sveučilišta vanjskim partnerima putem licenci i patenata. Jedan od najuspješnijih takvih primjera jest osnivanje prve biotehnološke tvrtke "Genentech", koja je obilježila početak biotehnološke industrije, a nastala je na temelju iskorištavanja patentnih prava na genetski proces kloniranja nastalih istraživanjem rekombinantne rDNA (Cohen-Boyer patent). Postupak zaštite vodio je najpoznatiji američki sveučilišni ured za licenciranje - Stanford's Office of Technology Licensing-OTL - a patentna prava držala su do 1997. godine sveučilišta Stanford i Kalifornijsko. Do 1997. godine (kada su patentna prava istekla) ostvareno je više od 400 licenci ovoga temeljnog otkrića i više od 30 milijuna dolara prihoda $u$ 1995./96. godini na temelju biotehnoloških proizvoda, kao što su inzulin, hormon rasta i sl. Sam OTL ostvario je od 1993. do 1994. više od 38 milijuna dolara od licenciranja 200 tehnologija.

Ipak, ovakav je uspjeh vrlo rijedak. Pavitt i Patel (1999.) navode kako patentna aktivnost samih sveučilišta daje samo djelomičnu i iskrivljenu sliku o doprinosu sveučilišta tehnološkoj promjeni, jer velika većina istraživanja ne završava patentom, već biva posredno ugrađena u tehnološke inovacije, odnosno patente drugih gospodarskih subjekata mehanizmima istraživačke suradnje i sl. Također, izvan bioznanosti i softwarea, aktivnosti kao patentiranje i licenciranje imaju manji utjecaj, što upućuje na to kako sva sveučilišta ne mogu primijeniti ovaj model. Problem koji se javlja jest i u komercijalnoj isplativosti, jer prihodi od licenci i patenata često ne mogu pokriti troškove djelatnosti vezane uz zaštitu prava intelektualnoga vlasništava (Gilsing i sur., 2010.).

Osnivanje kompanije "Genentech", koju su osnovali 1976. Robert Swanson, ulagač rizičnog kapitala, i Herbert Boyer, biokemičar te jedan od autora patenta, najbolji je primjer važno- 
DRUŠ. ISTRAŽ. ZAGREB GOD. 20 (2011), BR. $4(114)$

STR. 991-1013

DABIĆ, M., ŠVARC, J.: O KONCEPTU.. sti nastanka sveučilišnih spin-off poduzeća, nastalih na temelju iskorištavanja sveučilišnih istraživanja (Shane, 2004.). Stoga licenciranje / patentiranje i stvaranje novih poduzeća jesu važne poduzetničke djelatnosti sveučilišta (Agrawal, 2001;; Thursby i Thursby, 2007.).

Postoji nekoliko politika koje potiču spin-off aktivnosti, kao što su: ponuda isključive licence, dozvola za upotrebu sveučilišnih resursa za razvoj tehnologije, dopuštanje izumiteljima da zadrže manji udio autorskih prava, pristup kapitalu u početnoj fazi (Shane, 2004.). Zemljopisni položaj akademske institucije od velike je važnosti za nastanak spin-offsa, jer gospodarski, pravni i kulturni čimbenici u okolini utječu u velikoj mjeri na akademsko poduzetništvo, pa ono varira i u odnosu na pristup kapitalu, usmjerenosti na vlasnička prava, rigidnosti tržišta rada akademske zajednice, industrijskoga sastava područja itd. (Di Gregorio i Shane, 2003.; Shane, 2004.). Važan faktor u osnivanju spin-offsa jest dostupnost rizičnoga (venture) kapitala i poslovnih anđela, koji su spremni, za razliku od banaka, ulagati u visokorizične poduzetničke pothvate koji se temelje na znanstvenim dostignućima.

Transfer tehnologije podrazumijeva prijenos znanja iz akademske zajednice u svijet poduzetništva, za što je potrebna uključenost obiju strana: sveučilišta i industrije (Goldfarb i Henrekson, 2003.). Međutim, različitosti ovih dviju zajednica često sprečava tehnološki transfer. Sveučilište i znanstvenici dominantno rade na temeljnim istraživanjima, koja su dio obrazovne misije (Harris i Harris, 2004.) i stvaranja općeg dobra, dok je poslovnom sektoru najvažnije ostvarivanje vlastite konkurentnosti i profita. Tradicionalno, većina sveučilišta radi na području temeljnog istraživanja, ali izbjegava njegovu komercijalnu primjenu koja treba zadovoljiti potrebe industrije (Harris i Harris, 2004.). Jedan od problema jest nedovoljna povezanost industrije i sveučilišta, vidljiva iz nedostatne upoznatosti industrije s onim što se događa na sveučilištu, a s druge strane, sveučilišta nisu svjesna ciljeva industrije (Siegel i sur., 2004.; Bercovitz i Feldman, 2006.).

Ako pođemo od toga da je kultura indikator stvaranja i dijeljenja zajedničkih vrijednosti, onda su kulturne barijere jedan od najčešćih razloga koji utječu na efikasnost tehnološkoga transfera i suradnju industrije i sveučilišta (Siegel i sur., 2004.). U cilju zbližavanja ovih dvaju svjetova, poboljšanja komunikacije i kooperacije, sveučilišta (obično uz pomoć vlade) osnivaju tzv. intermedijarne institucije za transfer znanja i tehnologija, kao što su sveučilišni znanstveni i tehnološki parkovi te uredi za transfer tehnologije. Temeljna je zadaća ovih institucija da pomažu istraživačima u procjeni rezultata istraživanja i njihova komercijalnoga potencijala (tzv. tehnička i komercijalna evaluacija potencijala inovacije), a potom i u pravnoj zaštiti te komercijalizaciji inovacije. Nerijetko se ove insti- 
DRUŠ. ISTRAŽ. ZAGREB GOD. 20 (2011)

BR. 4 (114),

STR. 991-1013

DABIĆ, M., ŠVARC, J.: O KONCEPTU... tucije dopunjuju i poduzetničkim inkubatorima, poticajnim fondovima i sustavima nagrada za one koji su pridonijeli razvoju industrije (Harris i Harris, 2004.).

Međusektorska mobilnost kadrova izraženija je u anglosaksonskom sveučilišnom miljeu (npr. Programi "Teaching Company scheme" i "Knowledge transfer partnership" u Velikoj Britaniji), a manje u drugim europskim zemljama, zbog tradicionalne zatvorenosti akademske zajednice i stroge disciplinarne organizacije znanstveno-nastavnih djelatnosti. U Europi je, međutim, uključivanje sveučilišta u projekte lokalnoga i regionalnoga razvoja vrlo popularno kao dio poticanja regionalne konkurentnosti i razvoja poduzetništva koje se temelji na inovacijama. U Hrvatskoj je, primjerice, iz sredstava europskih predpristupnih fondova (IPA) osnovan 2009. Fond za ulaganje u znanost i inovacije, s ciljem uključivanja sveučilišta i javnih instituta u lokalni razvoj.

\section{OSVRT NA PODUZETNIČKO SVEUČILIŠTE U HRVATSKOJ}

Koncept poduzetničkoga sveučilišta u Hrvatskoj nije uhvatio dubljega korijena ni u sveučilišnoj zajednici ni u politici visokog obrazovanja i znanosti. Unapređenje djelatnosti sveučilišta uglavnom se vezuje uz izgradnju sustava kvaliteta sveučilišnog obrazovanja i istraživanja kroz procese integracije s Europskom unijom, kao što je Bolonjski proces, dok je doprinos gospodarskom rastu u drugom planu. Ocjenjuje se da $u$ hrvatskom visokom obrazovanju preteže "kvazitržišna" orijentacija, koja se uglavnom iscrpljuje u osnivanju privatnih visokih škola $\mathrm{u}$ poslovnoj sferi te $\mathrm{u}$ školarinama $\mathrm{u}$ sferi javnih visokih učilišta. To je do sada uglavnom rezultiralo koncentracijom studenata $\mathrm{u}$ društvenim znanostima, odnosno nedovoljnim usklađivanjem obrazovnih i tržišnih potreba (Babić i sur., 2006.). Sveučilišna istraživanja orijentirana k inovacijama realiziraju se mahom kroz istraživačke grantove koje dodjeljuju specijalizirane institucije (Poslovno-inovacijski centar Hrvatske, Hrvatski institut za tehnologiju) u okviru programa za poticanje suradnje znanosti i gospodarstva, a koji djeluju "izvan" sveučilišta kao dijelovi hrvatskoga inovacijskoga sustava (HIS) (Švarc, 2011.). Međutim, nema podataka o uspješnosti takvih sveučilišnih projekata, dok, isto tako, u javnosti nisu poznati slučajevi sveučilišnoga spin-offa, patenta ili nekoga drugog primjera koji bi svjedočili o utjecaju sveučilišta na razvoj.

Država je u sklopu HIS-a počela osnivati tehnološke centre u suradnji sa sveučilištima $\mathrm{i} / \mathrm{ili}$ fakultetima relativno rano, još 1996., najprije u Zagrebu, a potom u Osijeku, Dubrovniku i Rijeci. Međutim, ovi centri nisu prepoznati kao integralni dijelovi fakulteta/sveučilišta, pa djeluju na njihovoj periferiji kao inicijative resornoga ministarstva. Situacija se donekle promijenila 2005. godine, dakle nakon više od desetljeća učenja, 
DRUŠ. ISTRAŽ. ZAGREB GOD. 20 (2011), BR. $4(114)$

STR. 991-1013

DABIĆ, M., ŠVARC, J.: O KONCEPTU.. $\mathrm{s}$ Tempus projektima CREATE ${ }^{1} \mathrm{i}$ kasnije projektom OPUS, ${ }^{2} \mathrm{u}$ sklopu kojih su sveučilišta na vlastitu inicijativu pokrenula tri sveučilišna ureda za transfer tehnologije: u Splitu, Zagrebu i Rijeci. Najveći je iskorak napravilo Sveučilište u Rijeci, koje je uz Ured za transfer tehnologije osnovalo i Znanstveno-tehnologijski park Sveučilišta u Rijeci (STeP Ri), prvi sveučilišni znanstveno-tehnologijski park u Hrvatskoj. U kontekstu poduzetništva svakako valja spomenuti Tempus projekt FoSentHE, ${ }^{3}$ kojem je cilj uvođenje raznih oblika obrazovanja iz područja poduzetništva te potaknuti poduzetničke aktivnosti studenata.

Suradnja sveučilišta i gospodarstva u Hrvatskoj je tradicionalno vrlo slaba (Švarc i sur., 2011.; Dabić, 2001.), a međusektorska mobilnost nije dio sveučilišne prakse i šire inovacijske politike. Sama akademska zajednica opterećena je administrativnim obvezama koje prate obrazovnu funkciju i svoju ulogu vidi uglavnom $u$ publiciranju znanstvenih radova, na što je tjeraju sadašnji kriteriji procjene znanstvene izvrsnosti. U pogledu uvođenja modela trostruke uzvojnice, hrvatska se sveučilišta nalaze između pozicije ignoriranja i promatranja (Singer i Oberman Peterka, 2010.). Analize pokazuju kako u Hrvatskoj postoji niz razloga neefikasnosti transfera znanja između industrije i sveučilišta. Tako Singer i Oberman Peterka (2010.) navode institucijsku rigidnost sveučilišta, njihovu fragmentiranu organizaciju, nedostatak pravnog okvira, međusobno nepovjerenje poslovnoga sektora i sveučilišta, te nepostojanje stvarnoga mjerila (benchmarka). Intervjui s 20 vodećih znanstvenika Sveučilišta u Rijeci (STP, 2011.) s područja medicine, inženjerstva i ekonomije rezultirali su sljedećim razlozima: nedostatak sredstava, nedostatno vrijeme za istraživački rad, nerazvijeni sustav nagrađivanja te izostanak sustavnoga pristupa. Isto tako, istaknuto je da pojedinac ne može značajno pridonijeti transferu tehnologije, nego da je potrebna sustavna potpora sveučilišta i odgovarajuća strategija. Naravno, ne smiju se zanemariti ni etičke dileme, tj. postojanje prijepora o svrsishodnosti suradnje s industrijom.

Druge analize (Švarc i sur., 2011.) upozoravaju na to da je glavna zapreka suradnji nizak interes gospodarstva za suradnju s industrijom kao posljedica niske inovativne sposobnosti poduzeća, tj. primjene i tržišne eksploatacije rezultata istraživanja. U Hrvatskoj nema tržišta za znanstvene usluge i istraživanja, pa u zemljama s niskom inovativnom sposobnosti kakva je Hrvatska, dio odgovornosti za konzervativan stav sveučilišta i ovisnost o proračunu snosi i neambiciozni poslovni sektor. Pitanje je mogu li sveučilišta "sama od sebe", tj. bez gospodarstva kao treće uzvojnice, biti poduzetnička i na koji način.

Pojedini istaknuti znanstvenici ${ }^{4}$ drže da je hrvatskim sveučilištima nužna transformacija prema trećoj generaciji sveučilišta zbog neminovnoga rasta troškova obrazovanja i istraživanja i sve veće izloženosti globalnoj kompeticiji, uz istodob- 
DRUŠ. ISTRAŽ. ZAGREB GOD. 20 (2011)

BR. 4 (114),

STR. 991-1013

DABIĆ, M., ŠVARC, J.: O KONCEPTU... no smanjenje proračunskih sredstava. Nova generacija podrazumijeva uvođenje politike samoodržanja, tj. manje ovisnosti o državnom proračunu i voluntarizmu političkih elita. Pitanje je jesu li sveučilišta u Hrvatskoj sposobna za reforme prema samoodržanju i prerastanju u vodeće aktere gospodarskoga i društvenoga jačanja Hrvatske. Pritom valja uzeti u obzir da su sveučilišta do sada iskazala velik otpor promjenama, što je rezultiralo zaustavljanjem triju zakona, usmjerenih, između ostalog, i prema funkcionalnoj, pravnoj i financijskoj integraciji sveučilišta. ${ }^{5}$ To sugerira da nužnost promjena mora poteći iz samih sveučilišta, što onda jamči i uspješnost reformi.

\section{ZAKLJUČAK}

Globalna financijska kriza i smanjenje proračunskih sredstava oživjeli su pitanja uloge sveučilišta u gospodarskom razvoju i načinu financiranja. Cini se da sveučilištima ponovo predstoje fundamentalne promjene, uzrokovane ovaj put promjenama na globalnoj razini, koje su dovele do financijskih restrikrentskih sveučilišta s Dalekog istoka i sl. Poduzetničko sveučilište - te posebice treća generacija sveučilišta - nameću se kao korisne alternative postojećem tradicionalnom sveučilištu, opterećenom razdvojenošću obrazovne, istraživačke i poduzetničke misije, kao i pretjeranom utjecaju državne administracije i birokracije na njegovo funkcioniranje. Pitanje je, međutim, je li poduzetničko sveučilište moguće u svim okolnostima i u svim zemljama i koje su glavne zapreke njegova ostvarenja. Može li se generirati poduzetnička funkcija u zemljama u kojim "treća uzvojnica" - poduzeća - nisu spremna na suradnju sa sveučilištima, tj. na iskorištavanje i komercijalizaciju rezultata istraživanja i apsorpciju stručnjaka.

$\mathrm{S}$ druge strane, sva su sveučilišta, pa i ona u inovacijski manje razvijenim zemljama kao što je Hrvatska, izložena globalizaciji i internacionalizaciji, što ih neminovno sili na promjene. Stoga je malo vjerojatno da će sadašnji način funkcioniranja sveučilišta u krilu države, a bez suradnje s gospodarstvom, biti održiv na dulji rok. cionalne i kulturne promjene dugotrajan proces (Rasmussen i Borch, 2010.), pa je prije provođenja promjena važno postići određenu razinu razumijevanja i potpore $u$ instituciji i jačanje uvjerenja kod svih dionika u prikladnost promjene ciljeva. Shinn (1998.) zaključuje kako ne postoji gotov "recept" ni jedinstven ili jednostavan način na koji se interakcija znanosti i industrije može učinkovito ostvariti, pa svaka zemlja mora pronaći svoj put prema poduzetničkom sveučilištu. Sveučilišta se moraju prilagoditi, $i$ to tako da to odgovara njihovu "individualnom karakteru", vrsti obrazovanja, kapacitetima i docija, globalne mobilnosti kadrova i studenata, uspona konku-

Međutim, treba imati na umu kako je svaki oblik institu- 
DRUŠ. ISTRAŽ. ZAGREB GOD. 20 (2011), BR. $4(114)$

STR. 991-1013

DABIĆ, M., ŠVARC, J.: O KONCEPTU.. sadašnjoj aktivnosti. Trebaju birati one aktivnosti, tradicionalne ili poduzetničke, za koje smatraju da će najbolje pomoći razvoju gospodarstva i društvu. Clark također tvrdi kako će razvoj poduzetničke kulture biti mnogo lakši na manjim - specijaliziranim - i na onim sveučilištima koja imaju izraženije centralno upravljanje nego na većim sveučilištima, koja nisu tako specijalizirana i na kojima su odluke decentralizirane i donose se na nižoj razini (Clark, 1998., 2001.). Ipak, starost ili reputacija sveučilišta, a ni njegova veličina, nisu presudne za razvoj poduzetništva. Presudno je ponajviše to što uključivanje u gospodarski razvoj donosi sveučilištu određene rizike, kao što su gubitak vremena za poučavanje i temeljna istraživanja, povećana potreba za tajnošću istraživanja, koja kolidira s publiciranjem radova, povećanje unutarnjih sukoba te konačno i mogući novčani gubici (Slaughter i Leslie, 1999.).

Unatoč i pozitivnim i negativnim posljedicama usvajanja relativno nove ideologije poduzetničkoga sveučilišta, mnogi analitičari (Powers, 2004.; Clark, 2001.; Ranga i sur., 2003.) smatraju kako je trend ireverzibilan, pa se ne očekuje promjena postojećih tendencija u koncepciji sveučilišta u bližoj budućnosti. Vrlo je vjerojatno, stoga, da će ideja treće generacije sveučilišta zauzeti kritičko mjesto u promišljanjima o reformi sveučilišta i u politici visokog obrazovanja.

\section{BILJEŠKE}

\section{LITERATURA}

${ }^{1} \mathrm{http}: / /$ www.hrzz.hr/index.php?option=com_content\&view $=$ category \&layout $=$ blog\&id $=18 \&$ Itemid $=23 \&$ lang $=\overline{e n}$

2 http://opus.unizg.hr/

3 http://web.fosenthe.efzg.hr/

4 Vidi npr. razgovor s prof. dr. Perom Lučinom o razvoju znanosti i visokog obrazovanja u Hrvatskoj, objavljenom na Connect portalu u studenom 2011.

${ }^{5}$ Radi se o paketu triju zakona puštenih u javnu raspravu u listopadu 2010.: Zakon o sveučilištu, Zakon o visokom obrazovanju i Zakon o znanosti.

Agrawal, A. K. (2001.), University-to-Industry Knowledge Transfer: Literature Review and Unanswered Question. International Journal of Management Reviews, 3 (4): 285-302. doi:10.1111/1468-2370.00069

Allen, M. (2002.), The Corporate University Handbook, New York, USA, American Management Association.

Babić, Z., Matković, T. i Šošić, V. (2006.), Strukturne promjene visokog obrazovanja i ishodi na tržištu rada. Privredna kretanja $i$ ekonomska politika, 16 (108): 26-65.

Baldini, N. (2010.), Do Royalties Really Foster University Patenting Activity? An Answer from Italy. Technovation, 30 (2): 109-116. doi:10. 1016/j.technovation.2009.09.007 
DRUŠ. ISTRAŽ. ZAGREB GOD. 20 (2011) BR. 4 (114),

STR. $991-1013$

DABIĆ, M., ŠVARC, J.: O KONCEPTU...
Bercovitz, J. i Feldman, M. P. (2006.), Entrepreneurial Universities and Technology Transfer: A Conceptual Framework for Understanding Knowledge-Based Economic Development. The Journal of Technology Transfer, 31 (1): 175-188. doi:10.1007/s10961-005-5029-z

Bok, D. (2003.), Universities in the Marketplace: The Commercialization of Higher Education, Princeton, NJ, Princeton University Press.

Bolton, B. i Thompson, J. (ur.) (2004.) Entrepreneurs: Talent, Temperament, Technique, Great Britain, Elsevier.

Bouroche, M. (2001.), Academic Capitalism. Politics, Policies and the Entrepreneurial University. Journal of Research Administration, 2 (1): 33

Brint, S. (2000.), Higher Education. U: E. F. Borgatta i R. J. V. Montgomery (ur.), Encyclopedia of Sociology (str. 1178-1186), New York: Macmillan Reference USA.

Carroll, W. i Beaton, J. (2000.), Globalization, Neo-Liberalism, and the Changing Face of Corporate Hegemony in Higher Education. Studies in Political Economy, 62: 71-97.

Clark, B. R. (1998.), Creating Entrepreneurial Universities: Organizational Pathways of Transformation, Paris and Oxford, International Association of Universities and Elsevier Science Ltd.

Clark, B. (2001.), The Entrepreneurial University: New Foundations for Collegiality, Autonomy, and Achievement. Journal of the Programme on Institutional Management in Higher Education, 13 (2): 17-23.

COM (2006.), 208 final: 'Delivering on the Modernization Agenda for Universities: Education, Research and Innovation', http://eur-lex. europa.eu/LexUriServ/LexUriServ.do?uri=CELEX:52006DC0208:EN: HTML, pristup 4. 10. 2009.

Cozzens, S. E., Healey, P., Rip, A. i Ziman, J. (ur.) (1989.), The Research System in Transition, Proceedings of the NATO Advanced Study, Institute on Managing Science in the Steady State, Series D-Behavioural and Social Sciences, Vol. 57, str. 405, Kluwer, Academic Publishers, London.

Dabić, M. (2001.), Universities as Partners for Small and Medium Enterprise. Naše gospodarstvo, 47 (3-4): 345-357.

Decter, M., Bennett, D. i Leseure, M. (2007.), University to Business Technology Transfer - UK and USA Comparisons. Technovation, 27 (3): 145-155. doi:10.1016/j.technovation.2006.02.001

Di Gregorio, D. i Shane, S. (2003.), Why Do Some Universities Generate More Start Up Than Others? Research Policy, 32 (2): 209-227. doi:10.1016/S0048-7333(02)00097-5

Etzkowitz, H. (1998.), The Norms of Entrepreneurial Science: Cognitive Effects of the New University-Industry Linkages. Research Policy, 27 (8): 823-833. doi:10.1016/S0048-7333(98)00093-6

Etzkowitz, H. (2008.), The Triple Helix. University-Industry-Government, Innovation in Action, Routledge, London.

Etzkowitz, H., Gulbrandsen, M. i Levitt, J. (2000.a), Public Venture Capital: Government Funding Sources for Technology Entrepreneurs, Harcourt-Brace, New York.

Etzkowitz, H., Webster, A., Gebhardt, C., Regina, B. i Terra, C. (2000.b), The Future of the University and the University of the Future: Evolution of Ivory Tower to Entrepreneurial Paradigm. Research Policy, 29 (2): 313-330. doi:10.1016/S0048-7333(99)00069-4 
DRUŠ. ISTRAŽ. ZAGREB GOD. 20 (2011), BR. $4(114)$ STR. 991-1013

DABIĆ, M., ŠVARC, J.: O KONCEPTU..
Feldman, M. P. (1994.), The University and Economic Development: The Case of Johns Hopkins University and Baltimore. Economics Development Quarterly, 8 (1): 67-76. doi:10.1177/089124249400800105

Feldman, M. P. i Desrochers, P. (2003.), The Evolving Role of Research Universities in Technology Transfer: Lessons from the History of Johns Hopkins University. Industry and Innovation, 10: 5-24.

Freeman, C. (1988.), Japan: A New National System of Innovation. U: G. Dosi, C. Freeman, R. Nelson, G. Silverberg i L. Soete (ur.), Technical Change and Economic Theory (str. 330-349), Pinter Publisher Limited, London.

Gibb, A., Haskins, G. i Robertson, I. (2009.), Leading the Entrepreneurial University - Meeting the Entrepreneurial Development Needs for Higher Education Institution, NFCG, Said Business School, Oxford.

Gibbson, M., Limoges, C., Nowotny, H., Schwartzman, S., Scott, P. i Trow, M. (2006.), The New Production of Knowledge, the Dynamics of Science and Research in Contemporary Societies, Sage, London (9th reprint).

Gilsing, V. A., van Burg, E. i Romme, A. G. L. (2010.), Policy Principles for the Creation and Success of Corporate and Academic Spin-Offs. Technovation, 30 (1): 12-23. doi:10.1016/j.technovation.2009.07.004

Goldfarb, B. i Henrekson, M. (2003.), Bottom-Up Versus Top-Down Policies Towards the Commercialization of University Intellectual Property. Research Policy, 32 (4): 639-658. doi:10.1016/S0048-7333(02)00034-3

Goldstein, H. A. i Renault, C. S. (2004.), Contributions of Universities to Regional Economic Development: A Quasi-Experimental Approach. Regional Studies, 38 (7): 733-746. doi:10.1080/0034340042000 265232

Harris, D. i Harris, F. J. (2004.), Evaluating the Transfer of Technology between Application Domains: A Critical Evaluation of the Human Component in the System. Technology in Society, 26 (4): 551-565. doi:10. 1016/S0160-791X(04)00055-7

Hoye, K. i Pries, F. (2009.), 'Repeat Commercializers', the 'Habitual Entrepreneurs' of University-Industry Technology Transfer. Technovation, 29 (10): 682-689. doi:10.1016/j.technovation.2009.05.008

Keller, G. (1983.), Academic Strategy: The Management Revolution in American Higher Education, The John Hopkins University Press, Baltimore, London.

Kennedy, D. (1997.), Academic Duty, Harvard University Press, Cambridge, MD.

Kogan, M. i Kogan, D. (1983.), The Attack on Higher Education, London, Kogan Page.

Leydesdorff, L. i Etzkowitz, H. (1998.), The Triple Helix as a Model for Innovation Studies. Science and Public Policy, 25 (3): 195-203.

Lockett, A., Siegel, D., Wright, M. i Ensley, M. (2005.), The Creation of Spin-Off Firms at Public Research Institutions: Managerial and Policy Implications. Research Policy, 34 (7): 981-993. doi:10.1016/j.respol. 2005.05.010

Lumpkin, G. T. i Dess, G. G. (1996.), Clarifying the Entrepreneurial Orientation Construct and Linking It to Performance. Academy of $\mathrm{Ma}$ nagement Review, 21 (1): 135-172. doi:10.5465/AMR.1996.9602161568 
DRUŠ. ISTRAŽ. ZAGREB GOD. 20 (2011), BR. 4 (114),

STR. $991-1013$

DABIĆ, M., ŠVARC, J.: O KONCEPTU...
Lundvall, B. (ur.) (1992.), National Systems of Innovation: Towards a Theory of Innovation and Interactive Learning, Pinter Publishers, London.

Marginson, S. i Considine, M. (2000.), The Enterprise University: Power, Governance, and Reinvention in Australia, Cambridge, UK: Cambridge University Press.

Mowery, D. C., Nelson, R. R., Sampat, B. N. i Ziedonis, A. A. (2001.), The Growth of Patenting and Licensing by U.S. Universities: An Assessment of the Effects of the Bayh-Dole Act of 1980. Research Policy, 30 (1): 99-119. doi:10.1016/S0048-7333(99)00100-6

Mytelka, L. K. i Smith, K. (2002.), Policy Learning and Innovation Theory: An Interactive and Co-Evolving Process. Research Policy, 31 (8-9): 1567-1479. doi:10.1016/S0048-7333(02)00076-8

Nelson, R. (1993.), National Innovation Systems. A Comparative Analysis, Oxford University Press, New York.

Nelson, R. R. (2001.), Observations on the Post-Bayh-Dole Rise of Patenting at American Universities. The Journal of Technology Transfer, 26 (1-2): 13-19. doi:10.1023/A:1007875910066

Pavitt, K. i Patel, P. (1999.), Global Corporations and National Systems of Innovation: Who Dominates Whom? U: D. Archibugi, J. Howells i J. Michie (ur.), Innovation Policy in a Global Economy (str. 94-120), Cambridge, UK: Cambridge University Press.

Powers, J. B. (2004.), R\&D Funding Sources and University Technology Transfer: What Is Stimulating Universities to Be More Entrepreneurial? Research in Higher Education, 45 (1): 1-23. doi:10.1023/B: RIHE.0000010044.41663.a0

Ranga, L. M., Debackere, K. i Von Tunzelmann, N. (2003.), Entrepreneurial Universities and the Dynamics of Academic Knowledge Production: A Case Study of Basic vs. Applied Research in Belgium. Scientometrics, 58 (2): 301-320. doi:10.1023/A:1026288611013

Rasmussen, E. i Borch, O. J. (2010.), University Capabilities in Facilitating Entrepreneurship: A Longitudinal Study of Spin-Off Ventures at Mid-Range Universities. Research Policy, 39 (5): 602-612. doi:10. 1016/j.respol.2010.02.002

Ratinho, T. i Henriques, E. (2010.), The Role of Science Parks and Business Incubators in Converging Countries: Evidence from Portugal. Technovation, 30 (4): 278-290. doi:10.1016/j.technovation.2009. 09.002

Readings, W. (1996.), The University in Ruins, Cambridge, Harvard University Press.

Rosenberg, N. (1985.), The Commercial Exploitation of Science by American Industry. U: K. B. Clark, R. H. Hayes i C. Lorenz (ur.), The Uneasy Alliance: Managing the Productivity-Technology Dilemma (str. 19-51), Boston, MA: Harvard Business School Press.

Rosenberg, N. i Nelson, R. R. (1994.), American Universities and Technical Advance in Industry. Research Policy, 23 (3): 323-348. doi:10. 1016/0048-7333(94)90042-6

Rothaermel, F. T., Agung, S. D. i Jiang, L. (2007.), University Entrepreneurship: A Taxonomy of the Literature. Industrial and Corporate Change, 16 (4): 691-791. 
DRUŠ. ISTRAŽ. ZAGREB GOD. 20 (2011), BR. $4(114)$ STR. 991-1013

DABIĆ, M., ŠVARC, J.: O KONCEPTU..
Salter, A. J. i Martin, B. R. (2001.), The Economic Benefits of Publicly Funded Basic Research: A Critical Review. Research Policy, 30 (3): 509-532. doi:10.1016/S0048-7333(00)00091-3

Shane, S. (2004.), Academic Entrepreneurship: University Spin Offs and Wealth Creation, Cheltenham, UK Edward Elgar Publishing.

Shinn, T. (1998.), The Impact of Research and Education on Industry: A Comparative Analysis of the Relationship of Education and Research Systems to Industrial Progress in Six Countries. Industry and Higher Education, 12 (5): 270-289.

Siegel, D. S., Waldman, D. A., Atwater, L. i Link, A. N. (2004.), Toward a Model of the Effective Transfer of Scientific Knowledge from Academicians to Practitioners: Qualitative Evidence from the Commercialization of University Technologies. Journal of Engineering $\mathcal{E}$ Technology Management, 21 (1-2): 115-142. doi:10.1016/j.jengtecman. 2003.12.006

Singer, S. i Oberman Peterka, S. (2010.), Od ignoriranja do vođenja promjena - koju ulogu imaju sveučilišta u zemljama u razvoju? (Slučaj Hrvatske). Ekonomski vjesnik, 2: 307-314.

Slaughter, S. i Leslie, L. L. (1999.), Academic Capitalism: Politics, Policies, and the Entrepreneurial University, Baltimore, MD, The Johns Hopkins University Press.

Slaughter, S. i Leslie, L. L. (2001.), Expanding and Elaborating the Concept of Academic Capitalism. Organization, 8 (2): 154-161. doi:10. 1177/1350508401082003

Slaughter, S. i Rhoades, G. (2004.), Academic Capitalism and the New Economy: Markets, State, and Higher Education. Baltimore, MD, The Johns Hopkins University Press.

Soley, L. (2000.), The Selling of the Academy. U: The Advocate (chap.) Retrieved March 5, 2002, from http://www.newhavenadvocate.com/ articles/academy.html

STP (2011.), Evaluation of the Research Base of the University of Rijeka and It's Potentials for Collaboration with Industrial Partners, Science and Technology Project (STP) of EBRD, University of Rijeka, Internal Document.

Svarc, J. (2011.), Does Croatian National Innovation System (NIS) Follow the Path towards Knowledge Economy? International Journal of Technology Transfer and Commercialisation, 10 (2): 131-151. doi:10.1504/ IJTTC.2011.039130

Švarc, J., Lažnjak, J. i Perković, J. (2011.), Unintended Consequences of Innovation Policy Programmes: Social Evaluation of the Technological Projects Programme in Croatia. Innovation: Management Policy E Practice, 13 (1. 99.): 77-94.

Thursby, J. G. i Thursby, M. (2007.), University Licensing. Oxford Review of Economic Policy, 23 (4): 620-639. doi:10.1093/oxrep/grm031

Tornatzky, L., Waugaman, P. i Gray, P. (2002.), Innovation. U: New University Roles in a Knowledge Economy, Raleigh, Southern Growth Policies Board.

Vizek Vidović, V. i Bjeliš, A. (2006.), Entrepreneurialism at the University of Zagreb: Managing the Sustainability of Change. Higher Education in Europe, 31 (2): 157-193. 
DRUŠ. ISTRAŽ. ZAGREB GOD. 20 (2011)

BR. 4 (114),

STR. 991-1013

DABIĆ, M., ŠVARC, J.: O KONCEPTU...
Vogel, M. (2004.), Editor's Note. American Academic, 1 (1): 1-6.

Wissema, J. G. (2009.), Towards the Third Generation University - Managing the University in Transition, Edward Elgar Publishing, Cheltenham, UK.

Yale (2009.), http://www.yale.edu/oir/open/pdf_public/W069_Fac_ PatLic.pdf, pristup 25. 1. 2011.

Youtie, J. i Shapira, P. (2008.), Building an Innovation Hub: A Case Study of the Transformation of University Roles in Regional Technological and Economic Development. Research Policy, 37 (8): 1188-1204. doi:10.1016/j.respol.2008.04.012

\section{About the Concept of Entrepreneurial University: Is There an Alternative?}

\author{
Marina DABIC \\ Faculty of Economics and Business, Zagreb \\ Jadranka ŠVARC \\ Institute of Social Sciences Ivo Pilar, Zagreb
}

The crisis of the university in the 1970s, triggered by the reduction of budget resources, is experiencing its reprise today, as part of the global financial crisis. Although the contribution of universities to economic development through the standard functions of scientific research and education is considered unquestionable, it is questionable, whether these functions, in terms of the knowledge economy, are sufficient to retain the so far leading position of the universities as producers of knowledge and intellectual capital. This opens the door to new models of universities dominated by entrepreneurial university and its recent versions - the third generation universities. Both models emphasize the importance of the contribution of universities to economic development and their exposure to global competition. In this context, the paper analyzes the concept of entrepreneurial university, the historical context of origin, and theoretical and analytical frameworks that have led to a change in the paradigm of university research and the transformation from the traditional to the entrepreneurial university. The paper also explains the entrepreneurial activities of universities and provides a reference to the position of entrepreneurial universities in Croatia. The paper concludes that all universities, even those in countries with less developed innovation, such as Croatia, are exposed to globalization and internationalization, which inevitably forces them to change. Therefore, it is unlikely that the present way of functioning of universities under the state umbrella, without cooperation with the industry, will be sustainable in the long run.

Keywords: entrepreneurial university, the third generation universities, historical development, changing paradigms, theoretical frameworks, Croatia 
DRUŠ. ISTRAŽ. ZAGREB GOD. 20 (2011), BR. $4(114)$

STR. 991-1013

DABIĆ, M., ŠVARC, J.: O KONCEPTU..
Zum Konzept der Unternehmer-Universität: Gibt es denn eine Alternative?

\author{
Marina DABIĆ \\ Wirtschaftswissenschaftliche Fakultät, Zagreb \\ Jadranka ŠVARC \\ Ivo Pilar-Institut für Gesellschaftswissenschaften, Zagreb
}

Die auf die Kürzung staatlicher Zuschüsse zurückgehende Krise des Hochschulsystems in den 70er-Jahren erlebt heute, im Rahmen der globalen Finanzkrise, ein unwillkommenes Revival. Wenn auch der Beitrag der Universitäten zur wirtschaftlichen Entwicklung mittels ihrer Standardfunktionen der wissenschaftlichen Forschung und Ausbildung als unbestritten gilt, stellt sich doch die Frage, ob im Rahmen der Wissenswirtschaft diese Funktionen ausreichen, um den Universitäten ihre bisherige Führungsrolle bei der Erzeugung von Wissen und intelektuellem Kapital zu sichern. Die veränderte Lage schafft Voraussetzungen für neue Hochschulmodelle, unter denen die UnternehmerUniversität sowie, als deren jüngster Ableger, die Universität der dritten Generation herausragen. Beide Modelle stehen für die Notwendigkeit, die Wirtschaftsentwicklung von universitäter Seite zu fördern und sich auch auf universitärer Ebene dem globalen Wettbewerb zu stellen. Vor diesem Hintergrund analysieren die Verfasserinnen des Artikels das Konzept der UnternehmerUniversität, den geschichtlichen Kontext ihrer Entstehung sowie den theoretisch-analytischen Rahmen, innerhalb dessen sich der Wandel im Paradigma der wissenschaftlichen Forschung vollzog und die traditionelle Universität zur Unternehmer-Universität wurde. Des Weiteren erläutern sie die Tätigkeiten der Unternehmer-Universität sowie deren Stellung in Kroatien. Die Autorinnen kommen zu dem Schluss, dass sich der gesamte Hochschulbereich, selbst in weniger innovationsfreudigen Ländern wie Kroatien, der Globalisierung und Internationalisierung nicht entziehen könne und folglich zu Veränderungen gezwungen sei. Daher sei es wenig wahrscheinlich, dass die bisherige, unter der Ägide des Staates stehende Funktionsweise der Universitäten auf längere Sicht würde aufrechterhalten werden können.

Schlüsselbegriffe: Unternehmer-Universität, Universität der dritten Generation, geschichtliche Entwicklung, Paradigmenwechsel, theoretischer Rahmen, Kroatien 